\title{
Betty Fibichová, Alto in the Provisional and National Theatre
}

\author{
Markéta Koutná
}

Betty Fibichová was Fibich's second wife and she became famous as an opera singer in the Provisional and National Theatre in Prague (hereafter Národní divadlo). She was also a concerto singer, and she was a member of the organization of the first Czech girls' secondary school, called Minerva.

Betty Fibichová (family name Barbora Hanušová) was born on 16 March 1846 in Jilemnice. Until 1875 when she got married to Zdeněk Fibich, she was known as Betty Hanušová. The last performance with the name Hanušová was on 30 August 1875 in the role of Javotte (Leo Delibes: Manon). For the first time she used Fibich's surname in the same role on 9 September 1875. Her father was a miller and baker and he had three daughters (Betty was the second-born child). She started singing, and was taught by Augustin Appé, director of the Academy of Vocal Art in Prague, until 1859. Betty Fibichová began her singing career in the role of Nancy (Friedrich von Flotow: Martha) at the Germany Theatre in Karlovy Vary. She performed the same part in Olomouc on 29 October 1867. She received positive critical reviews about her voice but negative about her deficient education. Her last role in the Olomouc Theatre was Azucena (Giuseppe Verdi: Il trovatore) on 9 November 1867. Fibichova got the part of the abbess, thanks to Dr. František Ladislav Rieger, in the first of Bendl's operas Lejla (premiere in the Provisional Theatre on 4 January 1868). She succeeded and she became a singer for alto and mezzo-soprano specialisation in the Provisional Theatre (1868-1880). Her first role in this theatre was Hedvika (Gioacchino Rossini: Guillaume Tell). She continued to study singing with baritone Josef Lev.

Betty Fibichová and Zdeněk Fibich got married in October 1875. Fibich's first wife was Rủžena Hanušová-Fibichová, the younger sister of Betty. From this marriage they had twins (Elsa and Richard). Richard died soon after birth and then his mother fell ill. Looking after Elsa was Rủžena's last wish to Betty and Zdeněk before her death (on 4 October 1874). Elsa died in childhood. The new marriage developed from friendship, tolerance and confidence, rather than from love and urge. Betty and Zdeněk knew each 
other through professional relations. They lived in a house near the National Theatre (Ostrovní ulice 1) and they had one son Richard.

Betty Fibichová succeeded as a sacred and concerto singer as well. She sang the alto part of Beethoven's $9^{\text {th }}$ symphony in Beseda brněnská on 2 April 1879. For the first time Betty Fibichová and Marie Sittová introduced the Dvojzpěvy [Duets], Op. 38 composed by Dvořák (on 11 March 1880). She sang at a concert of the Jednota umělců hudebních [Music Artists' Society] in Prague on 23 December 1880, where she interpreted the alto part in Dvořák's cantata Stabat mater. She also sang in church and worked in the court chapel on Hradčany.

In 1881 the National Theatre was opened. Betty Fibichová became a new member of the National Theatre as well as a full ensemble member of the Provisional Theatre. Betty's first role at the Národní divadlo was Radmila from Smetana's opera Libuše. Her career ended exactly 23 years after her first performance in the Provisional Theatre, on 4 January 1891. Her reason for leaving the theatre was chest trouble (catarrhal croup). Her last role in the National Theatre was Lotinka in Dvoŕák's opera Jakobin [The Jacobin]. Nevertheless, Betty Fibichová was back on the theatre's stage in 1893 and 1895 (for example in Antonín Dvořák's Šelma sedlák [The Cunning Peasant]). Betty Fibichová died on 20 May 1901 in Prague and her tomb is in Vyšehrad cemetry.

Betty Fibichová was employed as a specialist of the alto and mezzo-soprano voice in the Provisional Theatre and then the Národní divadlo. She was better in low-voice singing parts, and she was said to be the specialist in this register in the Národní divadlo.

When she was nineteen she drew attention by her "powerful and beautiful alto". She was most successful between the years 1868-1881 when she interpreted Fides (G. Meyerbeer: Le prophète) which was one of the most difficult roles in her career. This role is unique thanks to its extensive music. A note by Otakar Hostinský on Fides's part survives: "In opera literature this role is really unique thanks to the vocal range. We can say that this role is able to spoil a voice. The singer needs to be a contralto, with a forceful central singing position and high voice as well! The vocalist usually sings Fides's part in an alteration by Meyerbeer."2

She participated in five premieres of Czech operas in the 1870s (e.g. A. Dvořák: Král a uhlír, 1875; A. Dvořák: Vanda, 1878; B. Smetana: Tajemstvi). At the beginning of Fibichová's career her voice was really strong. Betty Fibichová could sing really demanding roles. Her vocal range at this time was from $g$ to tone $b^{2}$. Hence, she could sing mezzosoprano parts.

Betty Fibichová interpreted many pivotal roles in the Národní divadlo as well (about five roles during one season). From 1881 to 1884 she was involved in six opera premieres (A. Dvořák: Tvrdé palice, Z. Fibich: Blaník, B. Smetana: Libuše, B. Smetana: Čertova stěna, K. Bendl: Karel Škréta and Z. Fibich: Nevěsta messinská). Her voice was still in good

\footnotetext{
1 Quotation from the archive of the Národní divadlo, signature P-679.

2 Otakar Hostinský, “Česká zpěvohra” [Czech Opera], Dalibor, 4 (1882), No. 21, p. 165.
} 
condition, otherwise she could not sing so many roles in the new and bigger Národní divadlo. Her vocal range was from a to tone $\mathrm{a}^{2}$.

Thanks to notices and articles in the periodical Dalibor from 1881 we can get a lot of information about her work schedule. For example we can read about her benefit performance on 22 April 1881 (W. A. Mozart: Le nozze di Figaro). Emanuel Chvála has written that it was a "Pleasure to see Mozart's Le nozze di Figaro again on the Czech stage thanks to our alto Betty Fibichová. There were so many people there. The audience greeted Mrs. Fibichová with bouquets of flowers and big applause."3

Her voice began to deteriorate, probably by constant effort of her vocal cords (especially in high tessitura). Fibichová's voice was not so well-balanced. She sang to the end of 1880 s but she performed in only one opera premiere (A. Dvořák: Jakobin). The number of articles in periodicals was less and less. We can read notices about Betty Fibichová in each issue of the periodical Dalibor in the beginning of the $1880 \mathrm{~s}$, but in the second half of the 1880s it is more difficult to find an article about her life or career. The really interesting thing is that any critique of her singing was always good.

The second cause of her worsening voice at that time was pneumonic catarrh. Betty Fibichová left the Národní divadlo in 1891. Sometimes she sang in the theatre after her exit-as a stand-in for ill singers. She could not have sustained continual engagements. We can find an article in the periodical Dalibor (10 January 1891) about her leaving the theatre: "Mrs. Fibichová's artistic working for the Czech opera scene will remain on the highest level in our memory forever as well as her noble character [...]"4

I have extracted information from an analysis of opera roles which Czech composers composed especially for Betty Fibichová (B. Smetana: Tajemství, Libuše, Čertova stěna; Z. Fibich: Blaník, Nevěsta messinská; A. Dvořák: Tvrdé palice). The tone $\mathrm{f}^{2} \mathrm{sharp}$ or $\mathrm{g}^{2} \mathrm{flat}$ was considered as the highest tone which Fibichová was able to sing without intonation trouble, which we can see in example 1 (from Smetana's opera Libuše and Tajemství). A special exception is the tone $\mathrm{g}^{2}$ in the opera Trvdé palice [The Stubborn Lovers] by Antonín Dvořák and the tone $\mathrm{a}^{2}$ in the opera Blaník by Zdeněk Fibich. We can see this in example 2.

\footnotetext{
3 Emanuel Chvála, “Česká zpěvohra”, Dalibor, 3 (1881), No. 13, p. 103.

4 “Česká zpěvohra”, Dalibor, 13 (1891), No. 3, p. 19-20.
} 


\section{Example 1}

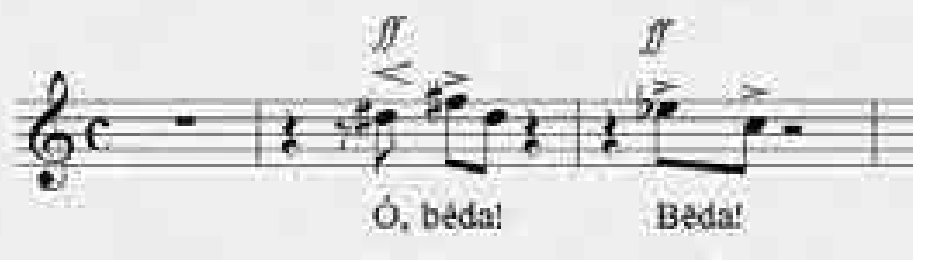

Bedřich Smetana: Tajemství; Act 2, Scene 7

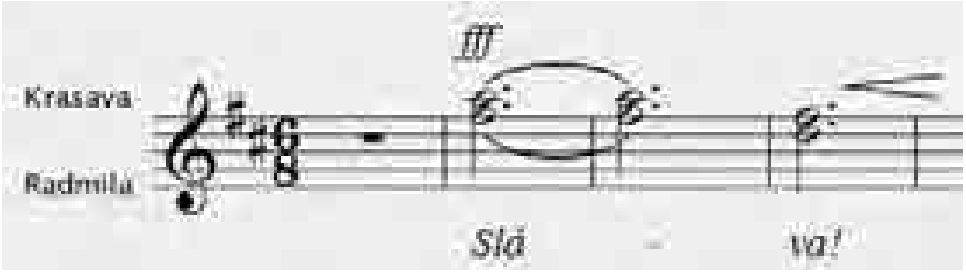

Bedřich Smetana: Libuše; Act 3, last scene with Radmila and Krasava

\section{Example 2}

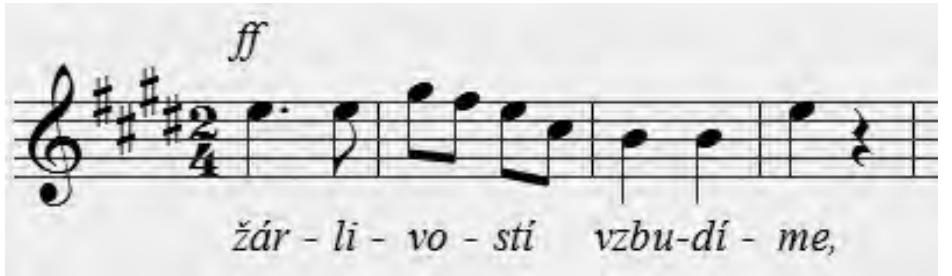

Antonín Dvořák: Tvrdé palice; Act 1, last scene

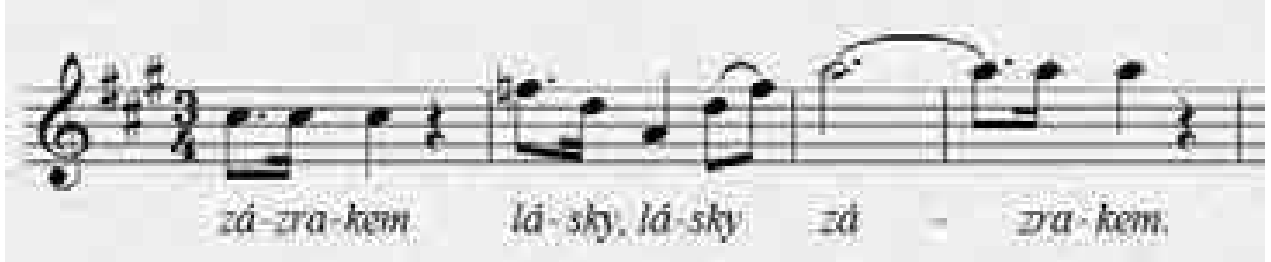

Zdeněk Fibich: Blaník; Act 3, Scene 2 
Betty Fibichová was famed as a specialist for classical and dramatic operas thanks to her voice but primarily thanks to her appearance: "Her figure was tall and pretty. She was serious and esteemed." ${ }^{5}$ It is clear that she was most successful in majestic roles like Fides (G. Meyerbeer: Le prophète), Azucena (G. Verdi: Il trovatore), Ulrica (G. Verdi: Un ballo in maschera), Radmila (B. Smetana: Libuše), and Donna Isabella (Z. Fibich: Nevěsta messinská). She worked in representative, classical and passive roles as well-Záviš (B. Smetana: Čertova stěna) and Panna Róza (B. Smetana: Tajemství). She also sang young princes and boys-from Záviš (B. Smetana: Čertova stěna) to Ratmir (M. I. Glinka: Ruslan and Lyudmila). But Betty Fibichová was also great in comic parts like Marcelina (W. A. Mozart: Le nozze di Figaro), and she performed in some comic roles in operetta. Unfortunately, she had a similar destiny to many women singers of the $19^{\text {th }}$ century who fell into obscurity soon after their death.

\title{
Betty Fibichová, Altistin des Interims- und des Nationaltheaters
}

\section{Zusammenfassung}

Der Beitrag ist der künstlerischen Tätigkeit der zweiten Frau Zdeněk Fibichs, Betty Fibichová, gewidmet, die als Solistin des Interims- und später des Nationaltheaters, als Konzertsängerin, aber auch z.B. als Ausschussmitglied des ersten Mädchengymnasiums Minerva im tschechischen Kulturleben viel geleistet hat. Es wird ihre Karriere dargestellt, wobei die Opern, in denen sie mit Erfolg aufgetreten ist, und die Rollen, die für sie geschrieben worden sind, nicht nur ihren Stimmumfang, sondern auch ihre Ausdrucks- und schauspielerischen Qualitäten festzustellen erlauben.

Übersetzt von Vlasta Reittererová

\section{Betty Fibichová, altistka Prozatímního a Národního divadla}

\begin{abstract}
Shrnutí
Příspěvek se zabývá uměleckou činností Betty Fibichové pro českou operní scénu ve druhé polovině 19. století. O Betty Fibichové je známo, že byla druhou ženou skladatele Zdeňka Fibicha, sólistkou Prozatímního a posléze Národního divadla, koncertní pěvkyní, ale např́ílad také členkou výboru prvního českého dívčího gymnázia Minervy. Studie mapuje průběh kariéry pěvkyně a specifikuje její hlasový rozsah. Zajímavou částí textu je

5 Quotation from the Archive of the Národní divadlo, signature P-679.
\end{abstract}


také sonda do typu oper, ve kterých Betty Fibichová vystupovala, ve kterých byla nejvíce úspěšná a které byly napsány prrímo s představou jejích hlasových a hereckých kvalit.

\section{Keywords}

Betty Fibichová; Provisional and National Theatre in Prague. 